\title{
Multiple tooth-rowed captorhinids from the early Permian fissure fills of the Bally Mountain Locality of Oklahoma
}

\author{
Aaron R.H. LeBlanc ${ }^{1, \star}$, A.K. Brar' ${ }^{1}$ W. $\mathrm{May}^{2}$, and R.R. Reisz ${ }^{1}$ \\ ${ }^{1}$ Department of Biology, University of Toronto Mississauga, 3359 Mississauga Road, Mississauga, \\ Ontario, L5L 1C6, Canada, aaron.leblanc@mail.utoronto.ca; amanpreet.brar@mail.utoronto.ca; \\ robert.reisz@utoronto.ca \\ ${ }^{2}$ Sam Noble Oklahoma Museum of Natural History, 2401 Chautauqua Ave., Norman, Oklahoma, \\ 73072, paleogatherings@yahoo.com
}

\begin{abstract}
Captorhinids are Paleozoic eureptiles that originated in the Late Pennsylvanian in Laurasia and dispersed across the major landmasses of Pangaea by the late Permian. Their evolutionary success as omnivorous and herbivorous members of Permian terrestrial communities has been attributed to the evolution of multiple marginal tooth rows. Multiple tooth rows evolved at least twice within Captorhinidae: once in the omnivorous Captorhinus aguti and again in the diverse subfamily of herbivorous moradisaurines. The earliest known moradisaurines co-occured with $C$. aguti in lower Permian strata of Texas; however C. aguti is also known from much older fissure fills in the famous Dolese Brothers quarry near Richards Spur, Oklahoma, suggesting that $C$. aguti preceded any other multiple-rowed captorhinid. Here we report on new material of multiple-rowed captorhinids from the lower Permian fissure fills of the Bally Mountain locality in Oklahoma, only 55 kilometers from Richards Spur. Some of this material is referable to Captorhinikos valensis, which was previously only known from younger strata in Texas, making this species the geologically and phylogenetically oldest moradisaurine. Furthermore, we determined that $C a$. valensis co-existed with $C$. aguti at Bally Mountain and we explore the potential for niche partitioning in these early captorhinids. Lastly, we assess the potential temporal and environmental differences between Bally Mountain and Richards Spur, in order to explain the abundance of herbivorous moradisaurines at Bally Mountain and the complete lack of moradisaurines at the neighbouring Richards Spur locality.
\end{abstract}

Key Words: moradisaurines, herbivory, fissure fills, dental anatomy, Captorhinidae, multiple tooth rows

\section{INTRODUCTION}

Captorhinids are Paleozoic amniotes that represent the first major radiation of terrestrial eureptiles (Modesto et al. 2014) much of it in the shadow of the more diverse and larger synapsids (Reisz 1997). Their initial diversification occurred in Laurasia in the Late Pennsylvanian and early Permian and included mainly carnivorous and omnivorous taxa with snout-vent lengths between 15-70 cm (Heaton 1979; Müller and Reisz 2005; Modesto et al. 2007). By the late Permian, herbivorous captorhinids had become much more dominant forms in terrestrial communities, with some taxa, including Moradisaurus from the upper Permian of Niger, having an estimated snout-vent length in excess of 2 meters (de Ricqlès and Taquet 1982; O'Keefe et al. 2005). Captorhinids in general are characterized by a

*corresponding author

Published 18 September 2015

(c) 2015 by the authors

submitted June 17, 2015; revisions received Sept. 10, 2015; accepted Sept. 15, 2015. Handling editor: Robert Holmes. stocky body and short limbs, and a number of interesting dental innovations that include a downturned premaxilla and multiple rows of marginal teeth, which formed from the interactions between tooth development and novel patterns of jaw growth (de Ricqlès and Bolt 1983; LeBlanc and Reisz 2015). One of the most interesting aspects of their evolutionary history is the apparent shift from carnivory to herbivory, with accompanying changes in dentition, and substantial increases in body size.

Their success as herbivorous and carnivorous members of Paleozoic communities has been attributed to their unique dentitions, which included the earliest record of multiple marginal tooth rows (Bolt and Demar 1975; de Ricqlès and Bolt 1983; LeBlanc and Reisz 2015). The emerging consensus is that at least two lineages of captorhinids independently evolved dental batteries composed of multiple tooth rows: once within the genus Captorhinus and again in the subfamily Moradisaurinae (Reisz et al. 2011; Modesto et al. 2014). Captorhinus aguti is the only multiple toothrowed species of the genus and its remains are known from the middle Clear Fork Group (sensu Hentz 1988) 
(Vale Formation, sensu Lucas 2006) of Texas and the cave deposits of the geologically older Dolese Brothers Quarry near Richards Spur, Oklahoma, U. S. A. (hereafter referred to as Richards Spur), both of which are early Permian in age (Olson 1954; Woodhead et al. 2010; Modesto et al. 2014). By comparison, the moradisaurines extended from the late early Permian (Kungurian) into the late Permian, were geographically widespread, and much more diverse (Reisz et al. 2011). The success of the moradisaurines may have been related to the evolution of high-fiber herbivory within the clade, given that even the earliest known moradisaurines possessed grinding batteries of teeth (Reisz 2006; Modesto et al. 2014). Records from the Vale Formation of Knox County, Texas indicate that early moradisaurines and Captorhinus aguti may have had some geographical and temporal overlap (Olson 1952; Modesto et al. 2014). Their co-occurrence in the lower Permian deposits of Texas suggest that $C$. aguti and the moradisaurines had adapted to different ecological niches that would have eased pressures of competition between the two related taxa. Interestingly, moradisaurines have never been found in the geologically older fissure fills of the Richards Spur locality in Oklahoma despite intense sampling at the site over many decades and the recovery of thousands of specimens of $C$. aguti and at least three single-rowed captorhinid taxa (Olson 1954; Fox and Bowman 1966; Heaton 1979; Modesto 1996, 1998; Reisz et al. 2015). This suggests that $C$. aguti may have had a broader temporal and geographic range compared to the earliest moradisaurines during the early Permian in North America. The earliest moradisaurines may thus have had to compete with an already established population of small-bodied captorhinids with multiple-rowed dentitions, which may have promoted their radiation into their alternative niche as high-fiber herbivores. These types of hypotheses, however, are sensitive to earliest occurrence data and whether the appearance of Captorhinus aguti preceded that of the first moradisaurines in the fossil record.

Here we present the first description of abundant multiple-rowed captorhinids from lower Permian fissure fills of the Bally Mountain locality (previously referred to as the "South Carnegie Site" by Olson 1967) in southwestern Oklahoma, which some consider to be equivalent in age to the Richards Spur site 55 kilometers to the southeast (Olson 1967; Donovan 1987), and assign some of this material to the early moradisaurine Captorhinikos valensis. This new occurrence extends the geographic and possibly the temporal ranges of the oldest moradisaurines, but also permits a more complete description of the dentition of this small and poorly known taxon. Furthermore, we identify tooth-bearing elements of Captorbinus aguti from the Bally Mountain locality, thus potentially extending the Captorhinus aguti-Captorhinikos valensis species overlap by nearly 20 million years, from the Sakmarian of Oklahoma to the Kungurian of Texas, assuming that the two fissure fill sites in Oklahoma are equivalent in age (Olson 1967). Given the abundance of tooth-bearing elements of Captorhinikos valensis from the Bally Mountain locality and the complete absence of any moradisaurine from the nearby fissure fills of Richards Spur, we examine the potential for differences in the stratigraphic positions and palaeoenvironments between these neighbouring fissure fill sites in Oklahoma.

\section{MATERIAL \& METHODS}

All of the material presented in this study was collected by W. May and was recovered from fissure fills of the lower Permian Bally Mountain locality (Table 1). The locality represents an abandoned limestone quarry on Bally Mountain in Kiowa County, Oklahoma (Donovan 1987; Busbey 1990). The fissures occur in the carbonate units of the Ordovician Kindblade Formation and the fissure fills were originally thought to be Late Pennsylvanian in age, however the presence of Captorhinus aguti at the site suggested an early Permian (Artinskian) age (Heaton 1979; Simpson 1979; Donovan 1987). According to preliminary reports, the fossils were recovered from sinkholes and collapsed fissures and presumably represent the washed-in remains of vertebrates that inhabited the area near the caves (Donovan 1987; Busbey 1990). This interpretation is supported by the fact that many of the specimens recovered from the locality show evidence of tumbling and water transport and are all disarticulated remains (Busbey 1990). Similar to Richards Spur, some specimens are completely impregnated with hydrocarbons, which stain the fossils black, whereas others appear beige or grey and show no evidence of invasive hydrocarbons.

All of the material was photographed by D. Scott using a Canon EOS 40D digital SLR camera with a Macro $1000 \mathrm{~mm}$ lens. Scanning Electron Microscopy was undertaken using a NeoScope ACM-5000 Scanning Electron Microscope (SEM). Specimens that were examined in the SEM were uncoated. Illustrations of OMNH 55796, 77533 , and 77534 were prepared by N. Wong Ken. Thin sections of ROM 67608 and 73638 were prepared following the methodology outlined by LeBlanc and Reisz (2015). The sections were photographed using a Nikon DS-Fi2 camera mounted to a Nikon AZ-100 microscope and NIS Elements (Basic Research) imaging software.

For the sake of brevity, Captorhinikos has been abbreviated to $C a$. throughout the manuscript. 
Table 1. Captorhinid jaw elements examined in this study from the Bally Mountain locality.

Specimen no.

OMNH 55796

OMNH 77529

OMNH 77530

OMNH 77531

OMNH 77532

OMNH 77533

OMNH 77534

OMNH 77535

OMNH 77536

OMNH 77537

OMNH 77538

OMNH 77546

OMNH 77547

OMNH 77548

OMNH 77552

OMNH 77553

OMNH 77556

OMNH 77528

OMNH 77539

OMNH 77549

OMNH 77550

OMNH 77554

OMNH 77540

OMNH 77551

OMNH 77555

OMNH 77541

OMNH 77542

OMNH 77543

OMNH 77544

OMNH 77545

ROM 67608

ROM 73638
Taxon

Captorhinikos valensis

Captorhinikos valensis

Captorhinikos valensis

Captorhinikos valensis

Captorhinikos valensis

Captorhinikos valensis

Captorhinikos valensis

Captorhinikos valensis

Captorhinikos valensis

Captorhinikos valensis

Captorhinikos valensis

Captorhinikos valensis

Captorhinikos valensis

Captorhinikos valensis

Captorhinikos valensis

Captorhinikos valensis

Captorhinikos valensis

Captorhinidae indet.

Captorhinidae indet.

Captorhinidae indet.

Captorhinidae indet.

Captorhinidae indet.

Captorhinus sp.

Captorhinus sp.

Captorhinus sp.

Captorhinus aguti

Captorhinus aguti

Captorhinus aguti

Captorhinus aguti

Captorhinus aguti

Captorhinikos valensis

Captorhinikos valensis
Specimen

R. dentary, incomplete

R. maxilla, anterior fragment

R. maxilla, posterior fragment

L. maxilla, anterior fragment

L. maxilla, posterior fragment

R. dentary, anterior fragment

L. dentary, anterior fragment

R. dentary, posterior fragment

$\mathrm{R}$. dentary, posterior fragment

L. maxilla, posterior fragment

L. maxilla, posterior fragment

L. maxilla, anterior fragment

L. maxilla, posterior fragment

L. maxilla, anterior fragment

R. maxilla, anterior fragment

R. maxilla, anterior fragment

L. maxilla, anterior fragment

R. premaxilla, complete

R. premaxilla, partial

R. premaxilla, partial

R. premaxilla, partial

L. premaxilla, partial

L. premaxilla, partial

R. premaxilla, partial

L. premaxilla, partial

R. maxilla, partial

R. dentary, posterior portion

R. dentary, anterior portion

R. dentary, posterior portion

$\mathrm{R}$. dentary, anterior portion

Partial dentary (sectioned)

Partial dentary (sectioned)

\section{SYSTEMATIC PALAEONTOLOGY}

REPTILIA Laurenti 1768

\section{CAPTORHINIDAE Case 1911}

MORADISAURINAE de Ricqlès and Taquet 1982

\section{CAPTORHINIKOS VALENSIS, Olson 1954}

\section{(Figs. 2-5, 7)}

Emended Diagnosis: Multiple-rowed moradisaurine distinguished by the presence of radiating rows of teeth on both maxilla and dentary. Teeth increase in size posteriorly in the multiple-rowed region, with the smallest teeth along the entire dentition being in the anterior positions in the multiple-rowed region. Tooth crowns of the multiple-rowed region possess a ring of raised enamel surrounding the occlusal tip of each tooth. Differs from other moradisaurines by the presence of two enlarged anterior maxillary teeth and a more densely denticulate pterygoid.

Locality and Horizon: All previously described specimens were recovered from the Leonardian (Kungurian) Vale Formation, Clear Fork Group in Knox County, Texas, U. S. A. (Modesto et al. 2014). The Bally Mountain locality represents an inactive limestone quarry at the northwest-most end of the Slick Hills in southwestern 
Oklahoma, approximately 55 kilometers northwest of the Richards Spur locality (Busbey 1990). The site represents an ancient cave system with extensive sediment infillings that were previously described as Late Pennsylvanian and later as Leonardian (Kungurian) in age. Preliminary reports suggested an abundance of disarticulated and worn material of Paleozoic tetrapods, including early synapsids, captorhinids, and the anamniote Doleserpeton, which rendered the site similar in faunal composition to the Richards Spur locality (Bolt 1969; Donovan 1987; Busbey 1990; Sullivan and Reisz 2002).

\section{ABBREVIATIONS}

Anatomical Abbreviations: de, dentary; dt, dentine; en, enamel; ep, emplacement pit; la, labial; li, lingual; $\mathrm{mp}$, maxillary process; $\mathrm{mx}$, maxilla; $\mathrm{np}$, nasal process; $\mathrm{rp}$, resorption pit; st, shed tooth; $\mathrm{t}$; first dentary tooth; $\mathrm{t} 2$, second dentary tooth; $\mathrm{t} 3$, third dentary tooth; vp, vomerine process; vs, vascular canal.

Institutional Abbreviations: FMNH, Field Museum of Natural History, Chicago, Illinois, U.S.A.; OMNH, Sam Noble Oklahoma Museum of Natural History, Norman, Oklahoma, U.S.A.; ROM, Royal Ontario Museum, Toronto, Ontario, Canada.

\section{DESCRIPTIONS AND COMPARISONS}

\section{Premaxillae}

Several captorhinid premaxillae have been collected from the Bally Mountain locality. These isolated elements can be assigned to two types. Many of these appear to belong to a species of Captorhinus, whereas others appear to represent a different captorhinid (Fig. 1A, C, E). The premaxillae of Captorhinus have four or five teeth with the mesial tooth being the largest (Fox and Bowman 1966; Heaton 1979; de Ricqlès and Bolt 1983). The second tooth is typically much smaller and the subsequent teeth steadily decrease in size distally. The second type of premaxilla also possesses four or five teeth, but differs from that of Captorhinus in that the second premaxillary tooth is as large as, or larger than the first tooth. The enlarged second premaxillary tooth also contributes to the more broadly arcuate shape of the tooth row in ventral view when compared to the premaxilla of Captorhinus (Fig. 1). The second tooth is also slightly procumbent, such that the tips of the first and second premaxillary teeth reach equally far mesially. In the premaxillae of Captorhinus, the tip of the second tooth is distal to the tip of the first (Fox and Bowman 1966; de Ricqlès and Bolt 1983) (Fig. 1). The shapes of the tooth crowns in both types of premaxillae are identical: the crowns taper to flat, spatulate tips and possess a pair of faint cutting edges on the lingual surfaces. Both types of premaxillae bear three processes: a dorsal nasal process, a medial vomerine process, and a lateral maxillary process. The dorsal extremities of the nasal processes in the premaxillae from Bally Mountain are often broken, but on one specimen of the new type of premaxilla (OMNH 77528), the maxillary and vomerine processes are complete (Fig. 1). The vomerine and maxillary processes both extend posteriorly, but the vomerine
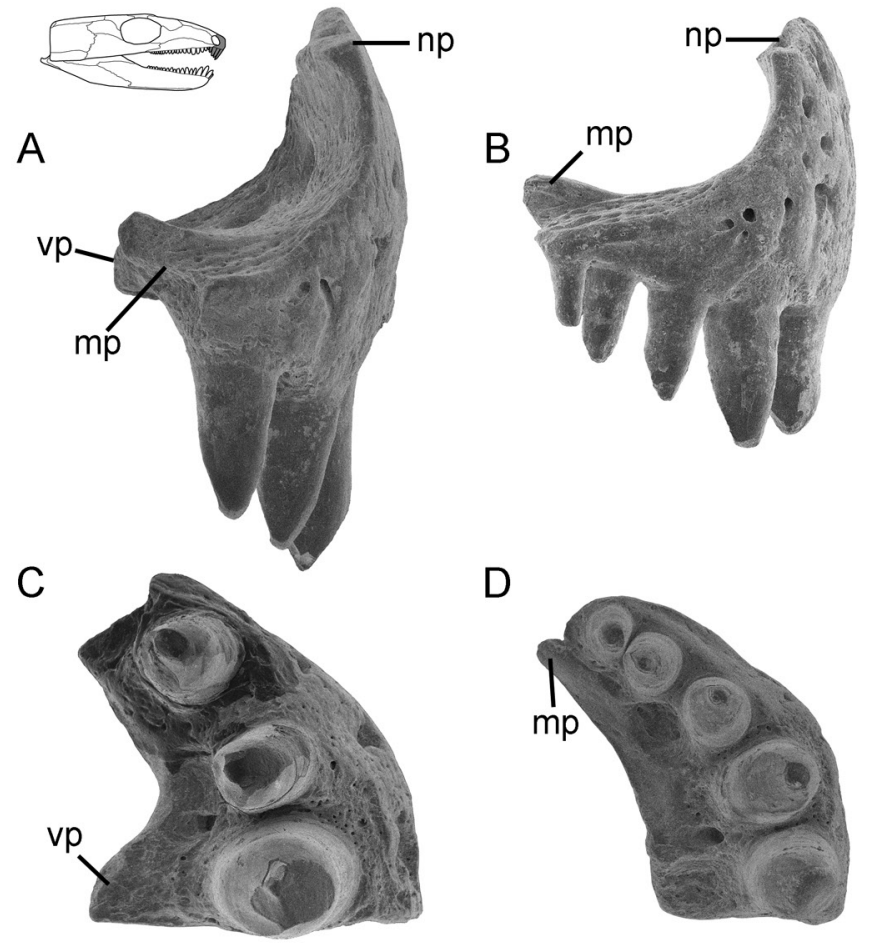

E
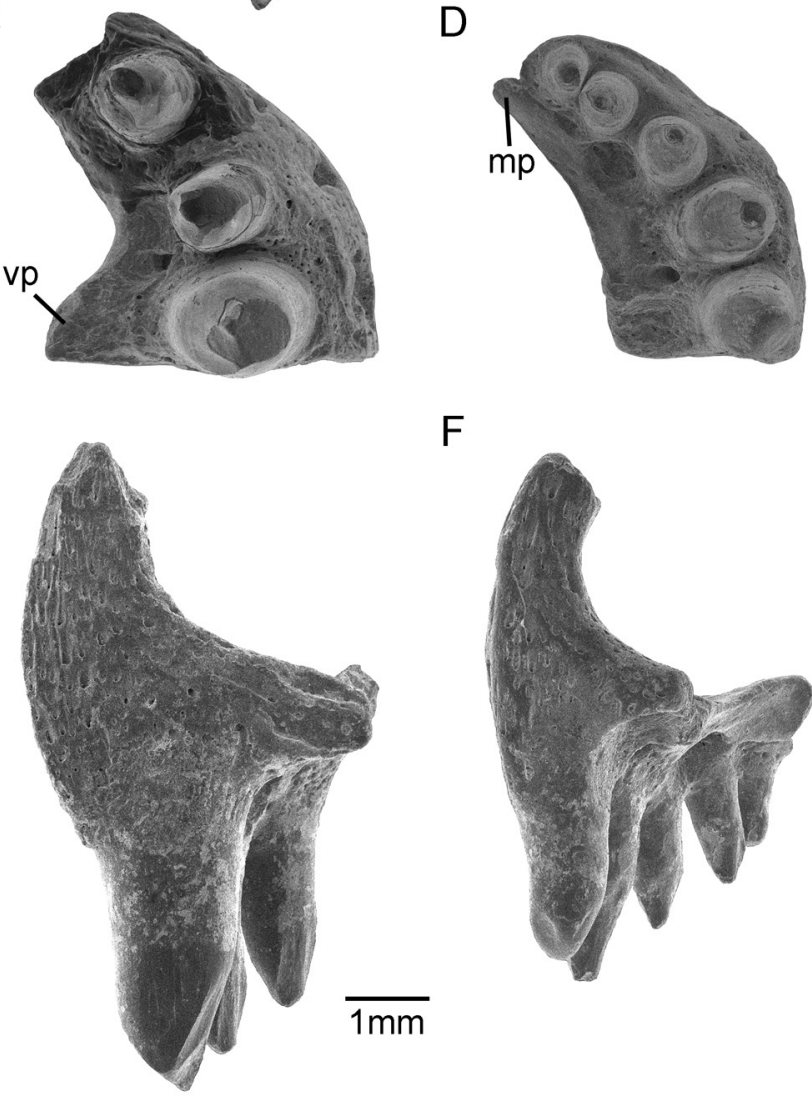

F

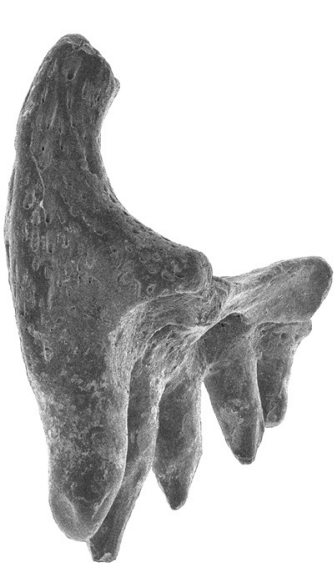

Figure 1. Comparisons of captorhinid premaxillae found at Bally Mountain. A, left premaxilla of Captorhinus (flipped for comparisons) in lateral view (OMNH 77540); B, unidentified captorhinid premaxilla in lateral view (OMNH 77528); C, premaxilla of Captorhinus in occlusal view; D, premaxilla of unidentified captorhinid in occlusal view; E, premaxilla of Captorhinus in medial view; F, premaxilla of unidentified captorhinid in medial view. 
processes projects more dorsally than does the maxillary process. This condition also occurs in premaxillae of Captorhinus and indicates that this second type of premaxilla was downturned, as in all other captorhinids (Fox and Bowman 1966; Modesto 1998). The anterior surface of the second premaxilla type is similar to Captorhinus in that it is perforated by numerous foramina (Fig. 1). Unfortunately, the second type of premaxilla cannot be confidently assigned to a taxon, given that they are always found disarticulated. However, we would argue that the differences in the size and orientation of the second premaxillary tooth indicate that these premaxillae do not belong to a species of Captorhinus, given that all species within the genus have a larger anterior premaxillary tooth (Fox and Bowman 1966; Heaton 1979; de Ricqlès and Bolt 1983).

\section{Maxillae}

At least two types of multiple-rowed maxillae are found at Bally Mountain. The first type possesses an anterior single-rowed region and a posterior multiple-rowed region with diagonally oriented tooth rows (Fig. 2). This type is readily referable to Captorhinus aguti based on the orientations of the rows of teeth and the morphology of the crowns in the multiple-rowed region (Fox and Bowman 1966; de Ricqlès and Bolt 1983; Modesto 1998). The teeth of the multiple-rowed region are ogival: they are laterally compressed, possess crenulated enamel apices, and the crowns terminate in mesiodistally aligned enamel crests (Fig. 2).

The second type of maxilla clearly belongs to a moradisaurine, based on the parallel alignment of the multiple rows of teeth. Although we were unable to recover a fragment with the anterior tip of the maxilla, the tapering anterior portions of the preserved maxillae all indicate the presence of an acuminate premaxillary process, which is found in all captorhinids (Modesto et al. 2014). The single-rowed region consists of at least five chisel-shaped teeth, although the full count is unknown. The multiple-rowed region is composed of five rows of small, bullet-shaped teeth with circular cross-sections (Fig. 2). The teeth of the single-rowed region possess short mesial and distal cutting edges, similar to those in both types of premaxillae from Bally Mountain. The preserved single-rowed regions all show an increase in tooth size distally, with the distal two teeth being the largest, forming a short "caniniform" region, similar to Captorhinus aguti, but unlike other moradisaurines (de Ricqlès and Bolt 1983; Dodick and Modesto 1995). The subsequent mesial-most teeth of the multiple-rowed area are significantly smaller and lack cutting edges (Fig. 2). The teeth in the multiple-rowed area are all similarly bullet-shaped and possess unusual crown ornamentation. Scanning Electron Microscopy (SEM) analysis revealed that each tooth consists of a pointed enamel apex, surrounded by a ring of enamel (Fig. 2K). This ring represents a low ridge that also forms the borders of shallow basins near the tip of the tooth crown on the lingual and labial sides. The tooth rows of the multiple-rowed region are nearly parallel to the long axis of the bone and diverge from each other distally due to a steady increase in the sizes of the posterior teeth in each row (Fig. 2). In other moradisaurines, the teeth in the multiple-rowed region of the maxillae exhibit a more modest increase in size posteriorly (Dodick and Modesto 1995; Reisz et al. 2011). In $C$. aguti, the maxillary teeth tend to be largest along the middle of the multiple-rowed region and decrease in size posteriorly (Modesto 1998). The teeth along the labial-most rows of the maxilla in the Bally Mountain moradisaurine have the smallest teeth and the teeth in the lingual rows are the largest (Fig. 2I, J, L, M).

\section{Dentaries}

As was the case with the maxillae from Bally Mountain, we were also able to identify two types of multiple-rowed captorhinid dentaries. The first type of dentary possesses three or more diagonally arranged rows of teeth in the multiple-rowed region. The six teeth in the single-rowed area bear mesial and distal cutting edges, whereas the distal, multiple-rowed teeth are ogival, indicating that these dentaries are referable to Captorhinus aguti (Modesto 1998). The second dentary type again belonged to a moradisaurine, based on the parallel rows of teeth in the multiple-rowed region (Dodick and Modesto 1995; Reisz et al. 2011).

The mesial-most dentary tooth is small, procumbent, and mesiodistally compressed similar to the first dentary tooth in Captorhinus aguti (Bolt and Demar 1975). The third tooth is the largest in the single-rowed area and is followed by three or four more teeth distally (Fig. 3). These teeth all bear mesial and distal cutting edges, similar to the anterior teeth of the maxillae. The teeth in the single-rowed area gradually decrease in size distal to the second dentary tooth. Unlike in C. aguti, the boundary between the single and multiple-rowed areas in the dentaries of the moradisaurine from Bally Mountain is well defined by a marked decrease in tooth diameter (Figs. 2, 3). The distal tooth of the single-rowed area is often preceded by three rows of very small, peg-shaped teeth. As in the maxilla of the moradisaurine, the dentary teeth in each row steadily increase in size, causing each row to widen distally. Each tooth is similar in crown morphology to those of the maxilla. At most, the dentaries possess four rows of teeth that radiate distally.

\section{Referral of Bally Mountain Moradisaurine to Captorbinikos valensis}

Whereas some of the captorhinid material from Bally Mountain is readily referable to Captorhinus aguti, the other multiple-rowed taxon is clearly a moradisaurine. 


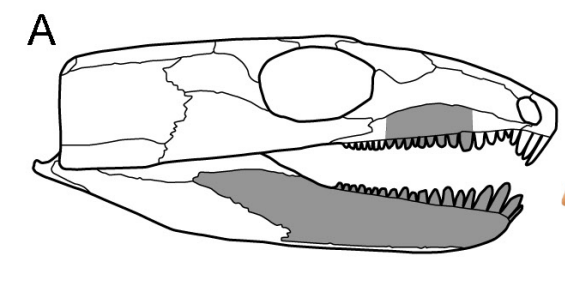

D

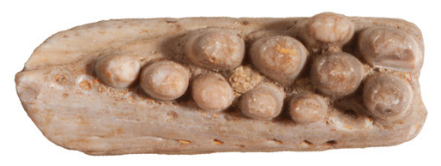

F
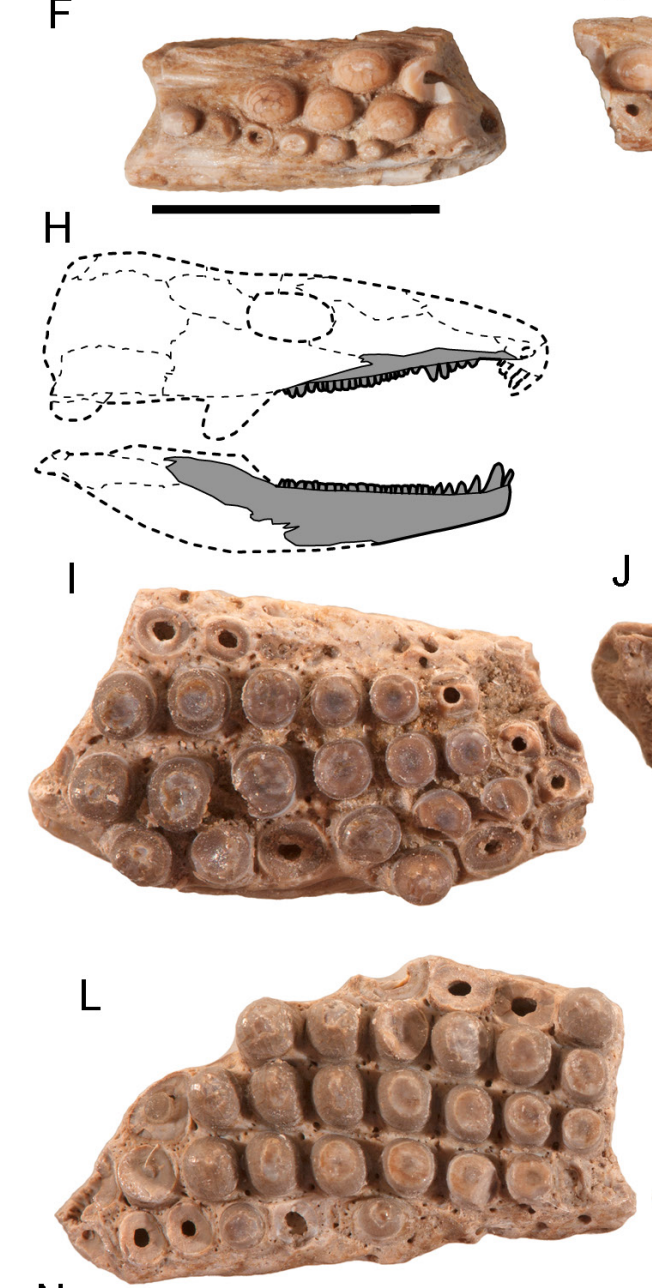

N

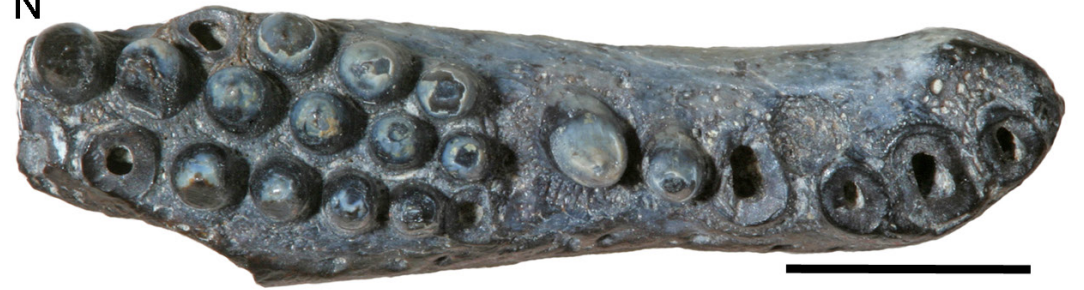

B

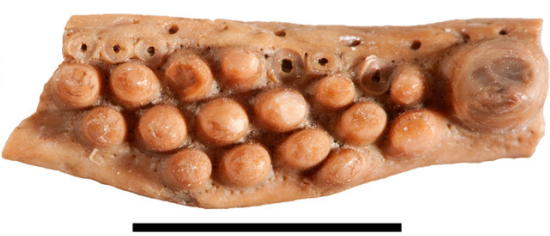

$\mathrm{E}$

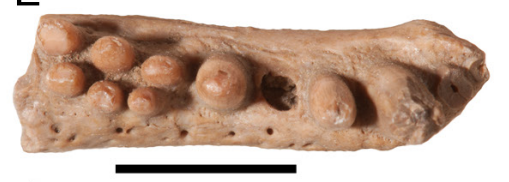

G

$\mathrm{J}$

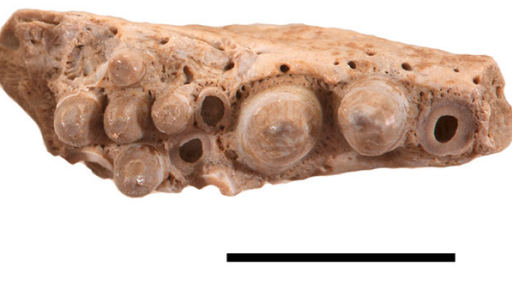

M

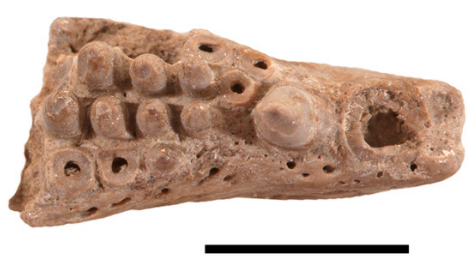

C
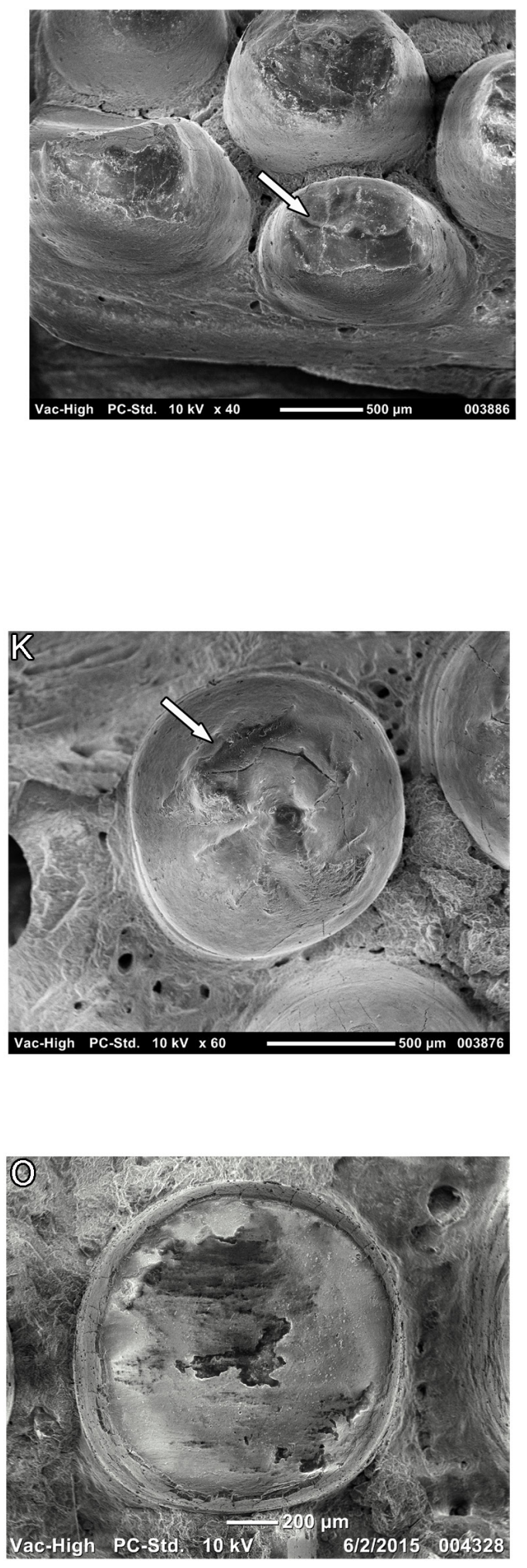
The parallel rows of marginal teeth indicate moradisaurine affinities, whereas the increasing diameter of the teeth along each row and the radiating tooth rows suggest that these remains are specifically referable to Captorhinikos valensis, known previously from potentially younger strata in Texas (Olson 1954; Modesto et al. 2014). The number of tooth rows in the maxilla and dentary of the Bally Mountain moradisaurine also match the number of rows in the holotype and referred materials of $\mathrm{Ca}$. valensis (Modesto et al. 2014). Furthermore, the dentaries and maxillae from Bally Mountain bear teeth that have identical crown morphologies to those of the holotype dentary (FMNH UR 101). The ring of enamel surrounding a pointed crown had not previously been described for $C a$. valensis, but it is clearly present on the teeth of the multiple-rowed region in FMNH UR 101 (Fig. 4). Thin sections of two partial dentaries (ROM 67608 and 73638) of Ca. valensis from Bally Mountain revealed that the enamel was not unusually thick when compared to that of other captorhinids from Richards Spur (see LeBlanc and Reisz 2015: figs. 4b, e, 6b; Reisz et al. 2015: fig. 1c). The enamel ridge in Ca. valensis was also only clearly visible in parasagittal sections through the tooth crowns and was formed primarily by a slight thickening of enamel and a minor occlusal extension of the underlying dentine (Fig. 4E, F). The change in shape of the dentine-enamel junction provides evidence for a developmental shift in the shape of the tooth prior to deposition of hard tissues, whereas enamel thickening alone would have indicated that the ridge had formed through an increase in the localized deposition of enamel only (Brink et al. 2015).

Unfortunately, no articulated material was recovered from our Bally Mountain sample and therefore we are uncertain as to the identity of the bearer of the second type of captorhinid premaxilla described here. Nevertheless, the abundant material of Captorhinikos valensis from Bally Mountain permits some minor additions to the knowledge of the dental
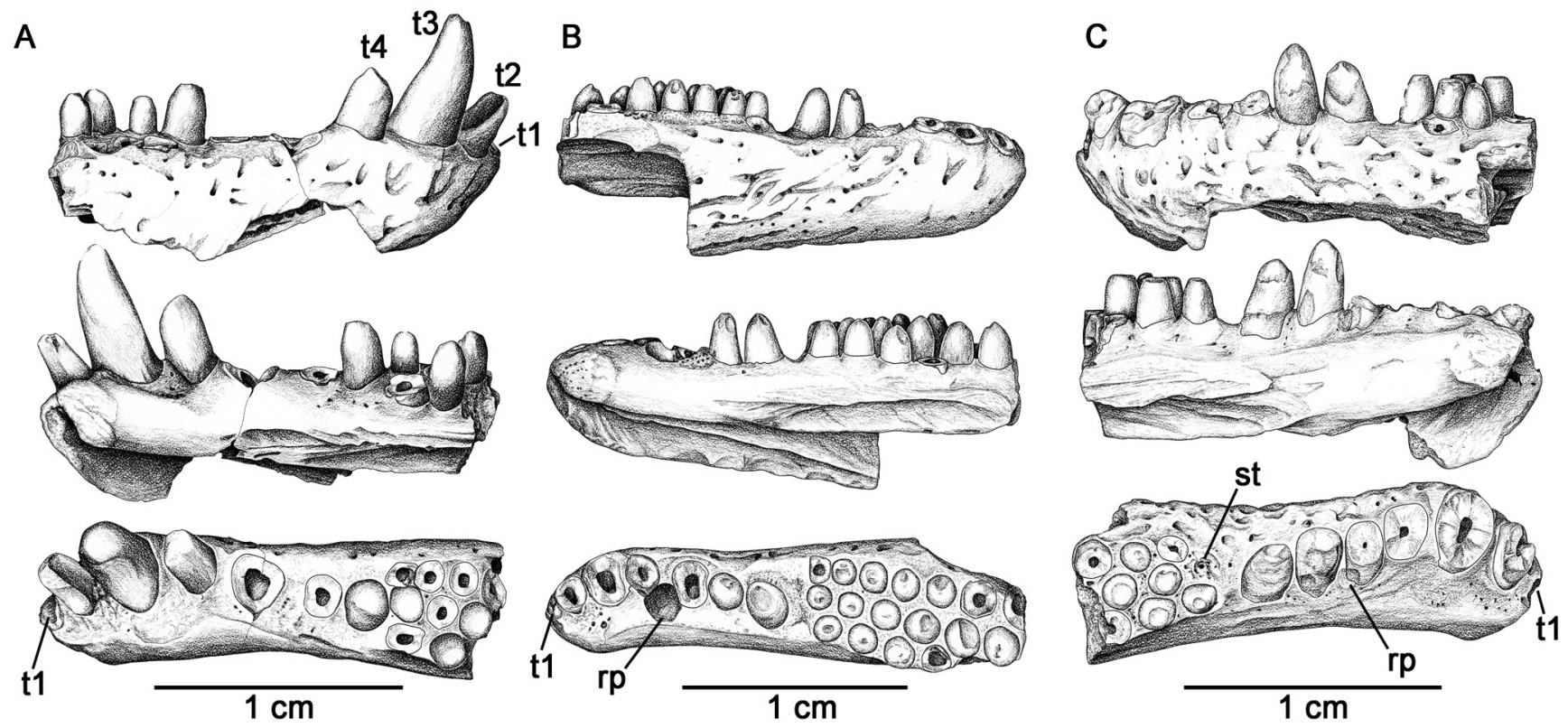

Figure 3. Three partial dentaries of Captorhinikos valensis from Bally Mountain. A, anterior portion of a right dentary (OMNH 77533) in lateral, medial, and occlusal views; B, anterior half of a right dentary (OMNH 55796) in lateral, medial, and occlusal views; C, anterior portion of a left dentary (OMNH 77534) in lateral, medial, and occlusal views. Note the presence of heavy tooth wear in the anterior portions of the multiple-rowed region.

Figure 2 Previous Page. Comparisons of captorhinid jaw elements found at Bally Mountain. A, reconstruction of Captorhinus aguti showing portions of the skull represented by fossil material in grey (modified from Heaton 1979); B, partial right maxilla of C. aguti (OMNH 77541); C, SEM of ogival teeth in the multiple-rowed region of a partial dentary of C. aguti. White arrow points to the enamel crest of the tooth crown; D, posterior half of a right dentary of C. aguti (OMNH 77542); $\mathrm{E}$, anterior half of a right dentary of C. aguti (OMNH 77543); F, posterior half of a right dentary of C. aguti (OMNH 77544); $\mathrm{G}$, anterior half of a right dentary of C. aguti (OMNH 77545); $\mathrm{H}$, reconstruction of Captorhinikos valensis showing preserved portions of the skull recovered from Bally Mountain (modified from Reisz 2006); I, posterior portion of a right maxilla of Ca. valensis (OMNH 77530); J, anterior portion of a right maxilla of Ca. valensis (OMNH 77529); K, SEM of the crown ornamentation of a lightly worn tooth in the multiple-rowed area of the maxilla. White arrow points to the enamel ridge that forms a ring around the tooth crown; $\mathrm{L}$, posterior portion of a left maxilla of $\mathrm{Ca}$. valensis (OMNH 77532); $\mathrm{M}$, anterior portion of a left maxilla of $\mathrm{Ca}$. valensis (OMNH 77531); $\mathrm{N}$, nearly complete right dentary of Ca. valensis (OMNH 55796); O, SEM of a heavily worn maxillary tooth. Scale bars $=5 \mathrm{~mm}$. 


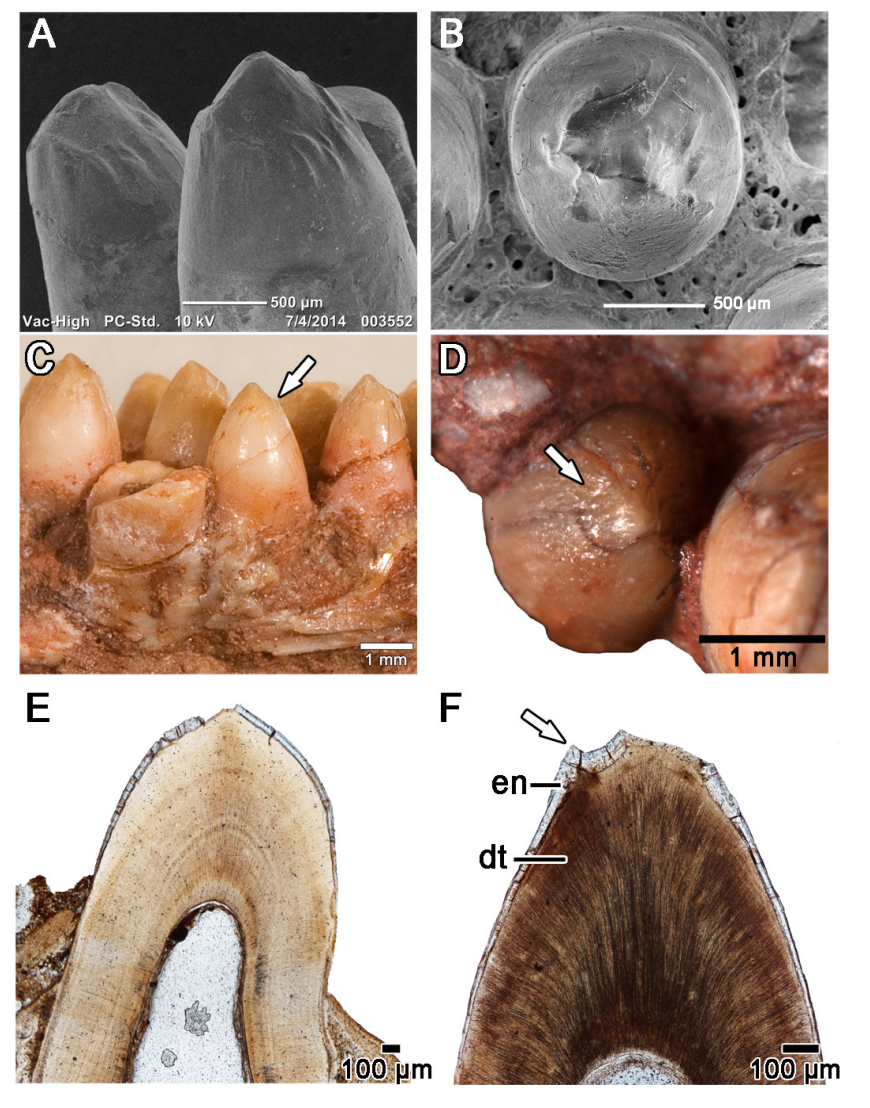

anatomy and mode of tooth replacement and tooth addition in this diminuative moradisaurine. First, the mesial-most dentary tooth is a small "symphyseal" tooth, which is preceded by two large, chisel-shaped teeth, all three of which are procumbent (Fig. 3). This morphology is reminiscient of the anterior dentary teeth of Captorbinus aguti, however the third dentary tooth in $C a$. valensis is proportionally much larger (Fig. 3A). Second, the anterior single-rowed area in the maxillae is remarkably heterodont, more so than in other moradisaurines. The teeth increase in size distally forming a "caniniform" region, similar to C. aguti (de Ricqlès and Bolt 1983). Third, the abundant remains of Ca. valensis allow us to conclude that the number of tooth rows in this taxon is not solely related to body size, given that we have found relatively large and small individuals with the same number of maxillary and dentary rows (Fig. 5). Previous authors have also found no correlation between the number of tooth rows and the size of individuals in Captorhinus aguti (Bolt and Demar 1975; de Ricqlès and Bolt 1983; LeBlanc and Reisz 2015). Finally, the presence of replacement pits lingual to the functional teeth in the single-rowed region (Fig. 3), coupled with the presence of emplacement pits (sensu LeBlanc and Reisz 2015) along the distal ends of each row suggest that teeth were replaced regularly in the mesial regions of the jaws and new teeth were added posteriorly along each row and with a relatively high frequency in $C a$. valensis (Fig. 5). Older teeth in the multiple-rowed area were shed along the labial margins of the jaws, as indicated by the shallow pits of
Figure 4. Comparisons of tooth crown morphology of Captorhinikos valensis specimens from Bally Mountain and the holotype dentary from the Vale Formation of Texas (FMNH UR 101). A, SEM of tooth crowns in lingual view in multiple-rowed area of a partial dentary (OMNH 77535) showing the ring of enamel encircling the tooth crown; B, SEM of same region of a dentary in occlusal view; $C$, closeup image of the tooth crowns in the multiple-rowed region in the Ca. valensis holotype (FMNH UR 101) showing identical crown morphology to those in A and B from Bally Mountain. $D$, closeup image of the occlusal surface of a posterior maxillary tooth from a referred specimen of $\mathrm{Ca}$. valensis from the Vale Formation of Texas (FMNH UR 2496); E, closeup image of a coronal section through a partial dentary of $\mathrm{Ca}$. valensis (ROM 67608, Thin Section no. 00646) showing the anatomy of the tooth crown (lingual is to the right of the image); F, closeup image of a parasagittal section through a partial dentary tooth of $\mathrm{Ca}$. valensis (ROM 73638, Thin Section no. 00287). Mesial is to the right of the image. White arrows indicate position of the ring of enamel.

spongy bone where teeth had apparently fallen out and the bone of the jaw had begun to fill in the space (Figs. 3C, 5C).

\section{PHYLOGENETIC ANALYSIS}

Given the phylogenetic position of Ca. valensis as the earliest moradisaurine (Modesto et al. 2014) the anatomy and precise phylogenetic relationships of this taxon are important for understanding the timing of the evolution of multiple tooth rows and high-fiber herbivory within Captorhinidae. Although the remains presented in this paper are fragmentary, some of the material of Captorhinikos valensis from Bally Mountain permitted the coding of additional characters from the original analysis by Modesto et al. (2014) to which we also added the minor character state changes for Captorhinus magnus and Labidosaurus as suggested by Reisz et al. (2015). Three additional characters were coded for $\mathrm{Ca}$. valensis (characters 4,29 , and 57) and one character was recoded (character 8) (Appendix 1). We then subjected this updated matrix to the same branch-and-bound search under maximum parsimony as Modesto et al. (2014) using PAUP* (Swofford 2002) in order to determine if this resulted in a different topology. The resulting single most parsimonious tree is identical to that of Modesto et al. (2014) and still recovers Ca. valensis as the phylogenetically oldest moradisaurine (Fig. 6; $\mathrm{TL}=147 ; \mathrm{CI}=0.633 ; \mathrm{RI}=0.779$; $\mathrm{RCI}=0.493$ ). The addition of these characters yielded slightly lower bootstrap support values after 1000 replicates for all of the nodes, but the clade supporting $C a$. valensis as a moradisaurine was still strongly supported (Fig. 6). 


\section{DISCUSSION}

\section{Patterns of Tooth Wear and Palaeoecology of Two Co-occurring, Multiple Tooth-rowed \\ Captorhinids}

The new material of Captorhinikos valensis and the presence of Captorhinus aguti from the Bally Mountain locality
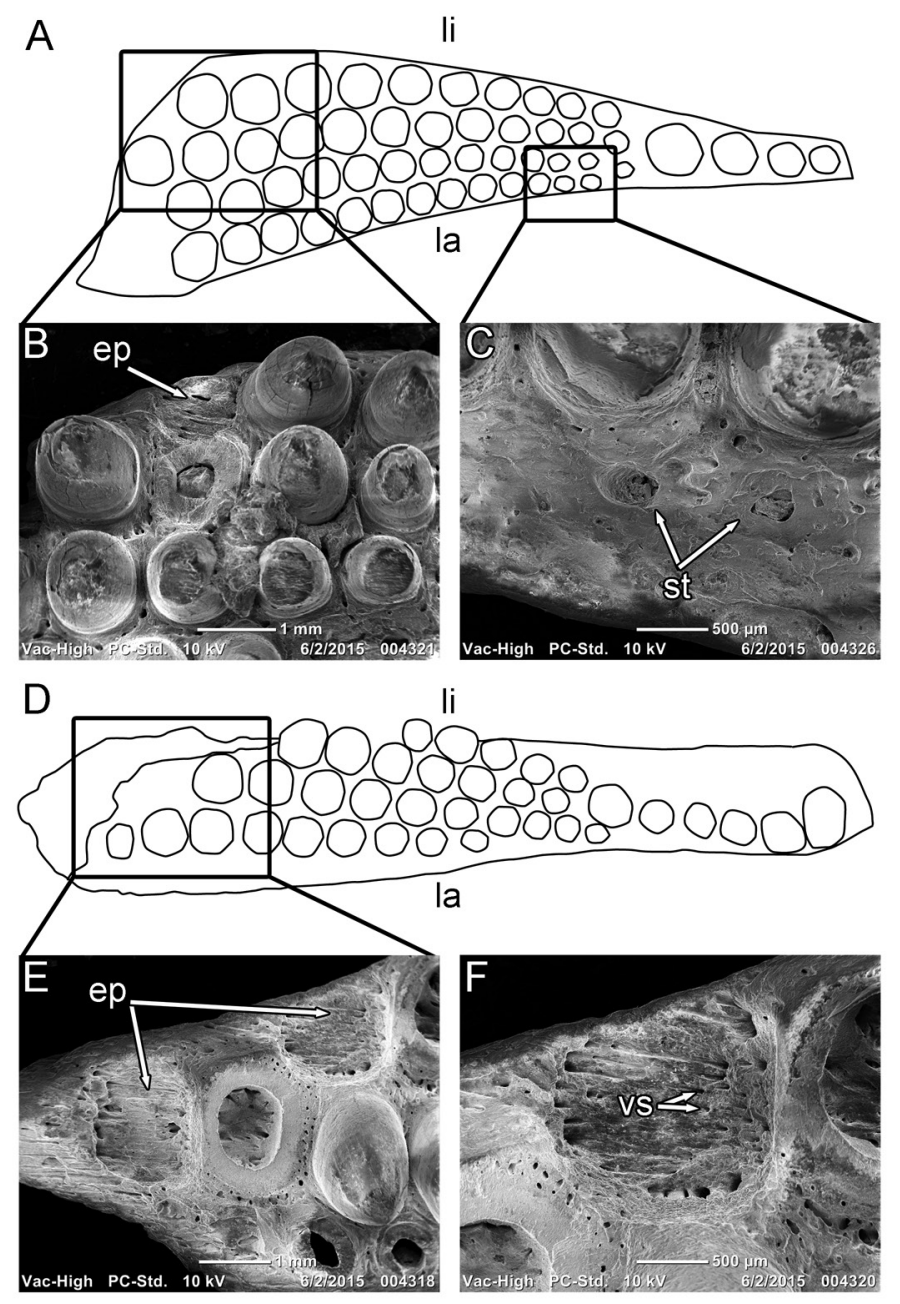

Figure 5. Tooth addition and tooth loss in the multiple-rowed marginal dentition of Captorhinikos valensis. A, generic reconstruction of a left maxilla of $\mathrm{Ca}$. valensis showing positions of SEM images in B and C; B, SEM image of posterolingual corner of maxilla fragment (OMNH 77537) showing early stages of tooth addition to the distal end of a tooth row along the lingual margin of the maxilla, as evidenced by an emplacement pit (sensu LeBlanc and Reisz 2015); C, SEM image of the partially resorbed bases of shed teeth along the mesial end of the labial-most tooth row; D, line drawing of the dentary of Captorhinikos valensis (FMNH UR 101) showing positions of SEM image in E; E, SEM image of the lingual margin of a partial dentary (OMNH 77536) showing the early stages of tooth addition along the distal ends of two tooth rows; F, closeup image of an emplacement pit, showing the resorption of the underlying jawbone, which exposed the underlying vascular spaces within the dentary bone. confirm that these two captorhinids co-existed during the early Permian in Oklahoma and Texas. This increases the geographical extent of the overlapping ranges of the two multiple-rowed captorhinids. Furthermore, the occurrence of $C a$. valensis at Bally Mountain is now the geologically oldest occurrence of a moradisaurine, given that the locality is considered equivalent in age to the famous Richards Spur locality in Oklahoma (mid-Sakmarian, roughly 289 MYA; see Woodhead et al. 2010). If these dates are correct, then the two multiple-rowed captorhinids co-existed for approximately 20 million years (Modesto et al. 2014), suggesting that Captorhinus aguti and the earliest moradisaurines had diverged in diet and ecology prior to this time. Dental wear patterns can help determine dietary prefer-

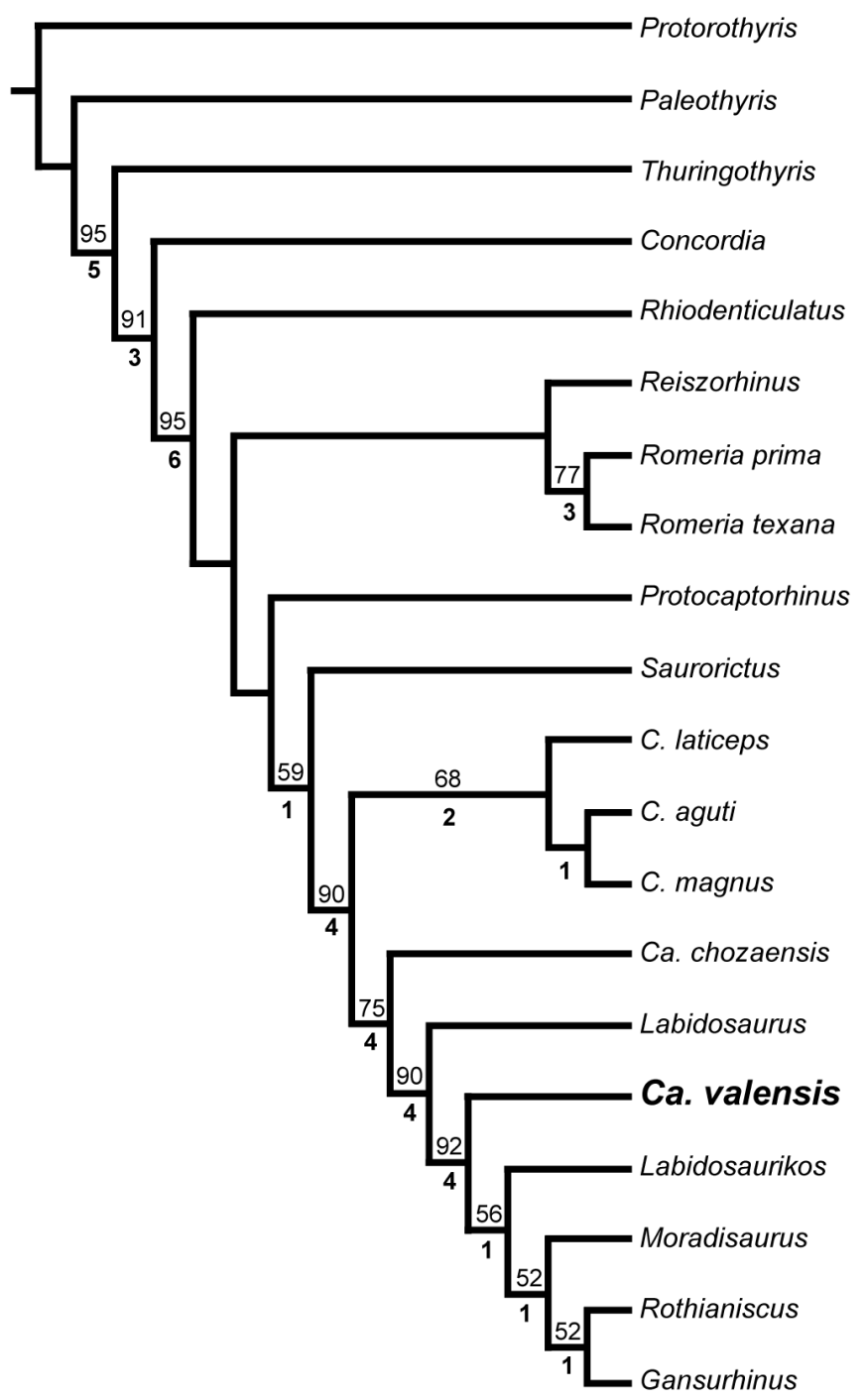

Figure 6. Single most parsimonious tree $(\mathrm{TL}=147 ; \mathrm{Cl}=$ $0.633 ; \mathrm{RI}=0.779 ; \mathrm{RCI}=0.493)$ resulting from the updated character codings for Captorhinikos valensis based on new Bally Mountain specimens. Numbers above the nodes indicate bootstrap support. Numbers below nodes indicate decay indices. 
ence in fossil taxa (Reisz 2006) and these patterns differ significantly between the two taxa (Fig. 7). Individual teeth in Captorhinus aguti are either worn only along the mesial and distal ends of the enamel crest, or along the labial or lingual face of the crown (Fig. 7A-E). Across the rows, the lingual-most teeth of $C$. aguti are always unworn, whereas most of the labial teeth show evidence of light to moderate tooth wear. The predominant gradient of tooth wear is therefore oriented labio-lingually. Overall, tooth wear is not as extensive in C. aguti as it is in Captorhinikos valensis (Fig. $7 \mathrm{~F}-\mathrm{L}$ ). Furthermore, the tooth wear in C. aguti is restricted to either the labial or lingual surfaces of the tooth crowns, suggesting that only one upper and one lower tooth sheared past one another. The mesio-distally oriented enamel crests on the teeth of C. aguti would have assisted in shearing food as well.

By comparison, many of the teeth of $C a$. valensis are worn flat and were clearly forming grinding surfaces along the mesial portions of the multiple-rowed regions of the jaws. The teeth of $C a$. valensis also show a drastically different wear pattern along and across the tooth rows compared to Captorhinus aguti (Fig. 7). Lightly worn teeth are primarily restricted to the distal ends of each row, moderately worn teeth further mesially, and the heaviest wear is associated with the mesial-most teeth. This dental wear pattern is nearly identical to that of the Triassic rhynchosaurs (Benton 1984), where the gradient of tooth wear is mainly oriented mesio-distally. A slight labio-lingual wear gradient is also present, but it is much less pronounced.

Figure 7. Comparisons of dental wear patterns between Captorhinus aguti and Captorhinikos valensis. A, Reconstruction of the skull of Captorhinus aguti (modified from Heaton 1979); B, Closeup image of the multiple-rowed area of a right dentary of C. aguti from Richards Spur (OMNH 15138) showing positions of unworn (blue), lightly worn (red), and heavily worn (green) teeth. Lingual is towards the top of the page, anterior is to the right; C, SEM image of an unworn tooth of C. aguti; D, lightly worn tooth; E, heavily worn tooth; F, reconstruction of the skull of $\mathrm{Ca}$. valensis (modified from Reisz 2006); G, interpretation of dental wear patterns across the maxilla and dentary of $\mathrm{Ca}$. valensis; $\mathrm{H}$, dental wear patterns along the posterior portion of a left maxilla (OMNH 77538). Note that unworn teeth (blue) tend to be restricted to the distal ends of each tooth row; l, dental wear patterns along the multiple-rowed area of a partial left maxilla (OMNH 77532). The heaviest tooth wear (green) is concentrated along the mesial ends of each tooth row; I, SEM image of very lightly worn maxillary tooth with lingual and labial wear facets; J, SEM image of lightly worn maxillary tooth with a single large wear facet extending to the tip of the crown; $\mathrm{K}$, heavily worn tooth; L, striations along the labial surface of a lightly worn tooth crown indicate fore and aft motion between upper and lower jaws.
Despite being disarticulated elements, a survey of a large number of specimens shows that tooth wear is much more pronounced on the maxillae than on the dentaries in $\mathrm{Ca}$. valensis, however dental wear is still most extensive on the

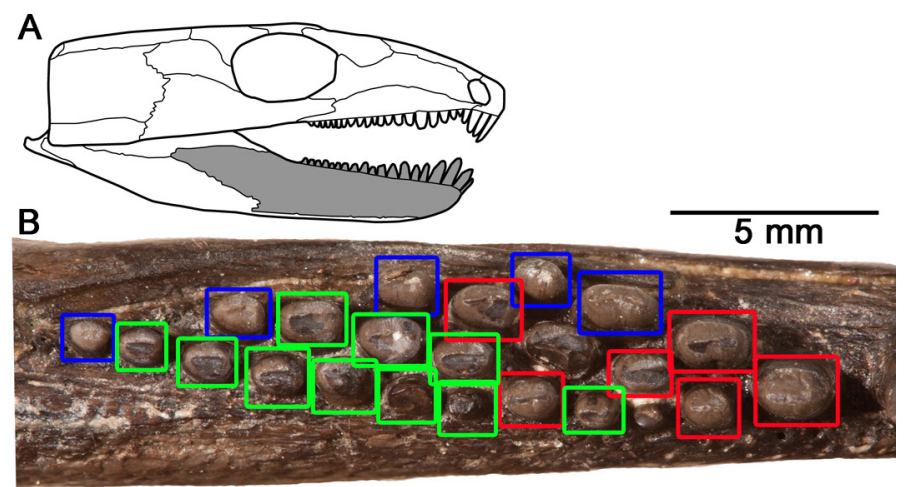

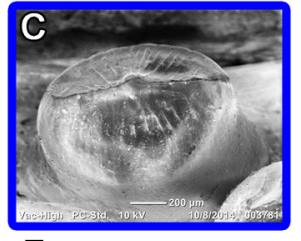
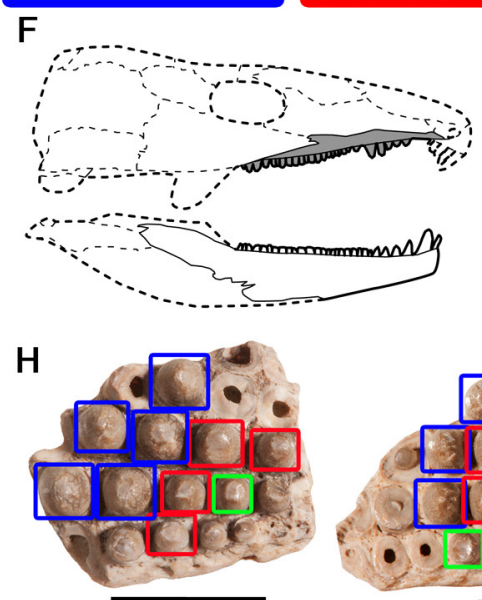

$5 \mathrm{~mm}$
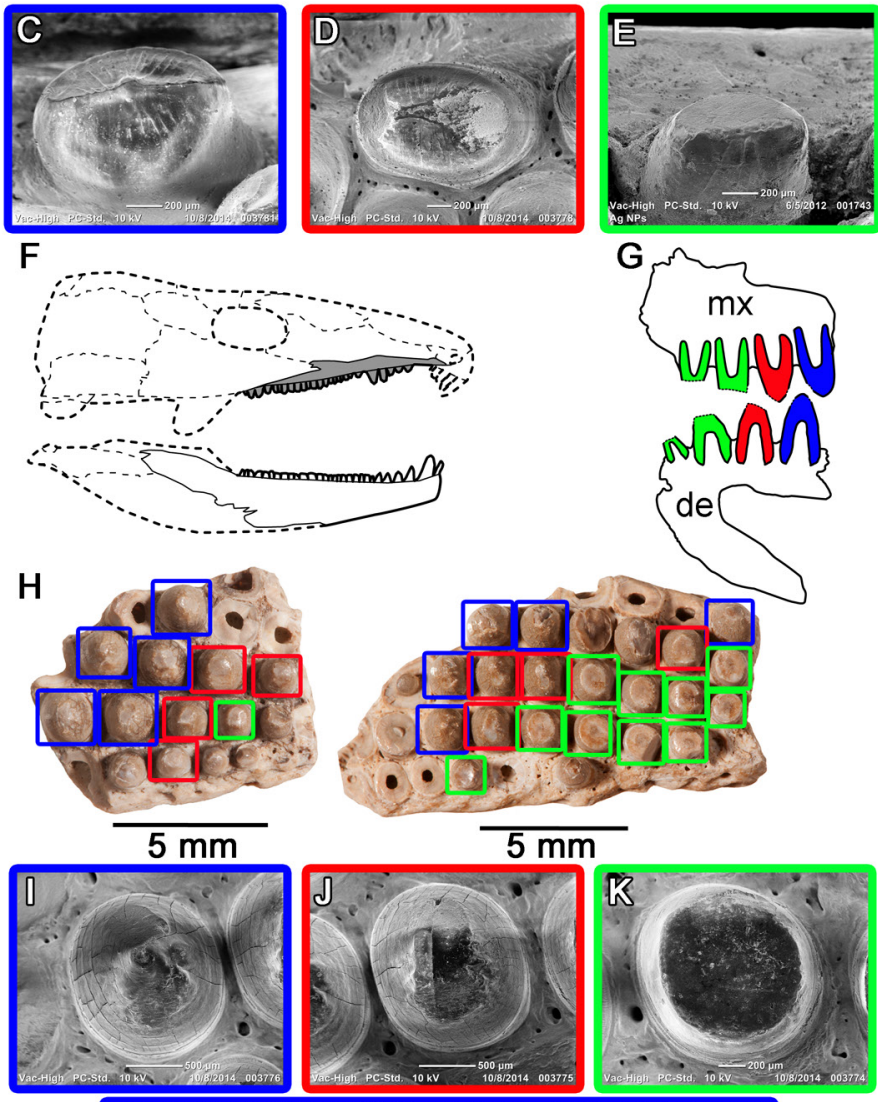

\section{G}
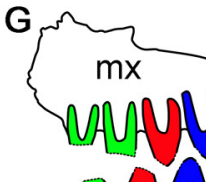
onoth de
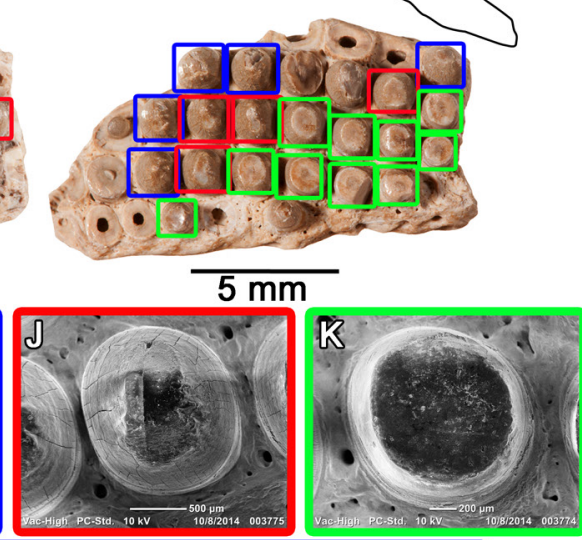

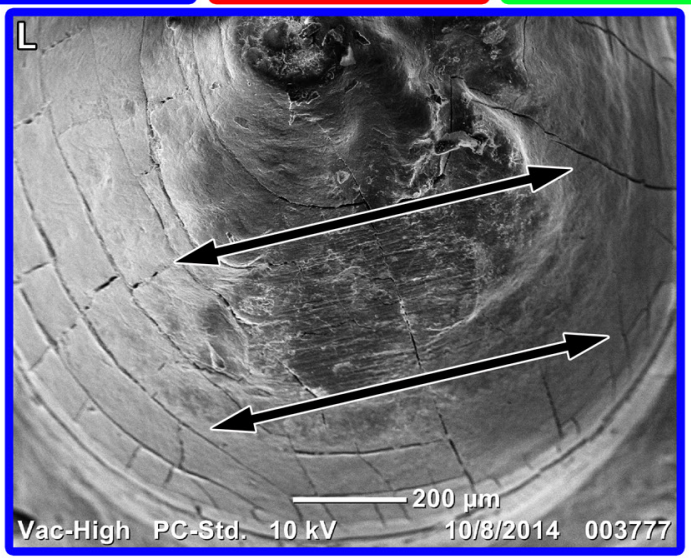


mesial teeth of the multiple-rowed regions of the dentaries (Fig. 7). Furthermore, the presence of two wear facets on the lingual and labial sides of the lightly worn teeth show that the upper teeth and lower teeth contacted in an interlocked fashion, and that food grinding was accomplished by propalineal movements of the lower jaws across the maxillary dentition (Fig. 7L). Even the lightly worn teeth of the distal and lingual MR regions show evidence of tooth wear on both the labial and lingual sides of the crowns. The ridges and small basins of enamel at the tips of the crowns would have been worn down first, followed by the underlying dentine. Heavily worn teeth possessed no enamel, but did not have exposed pulp cavities. From these data, it seems that even the earliest moradisaurines were adapted to grinding food material and show clear evidence of tooth occlusion. Despite having independently evolved multiple-rowed dentitions, the earliest moradisaurines and Captorhinus aguti used these dentitions in entirely different manners. Captorhinus aguti was probably more omnivorous and did not exhibit a true grinding dental battery, because the teeth sheared past their counterparts, whereas the moradisaurines exhibited extensive dental occlusion and tooth wear, presumably to pulverize fibrous plant material.

\section{Significance of the Presence of Captorbinikos valensis at Bally Mountain}

The presence of an herbivorous moradisaurine from the early Permian fissure fills of Oklahoma raises intriguing questions about the temporal and geographical distribution of early Permian captorhinids across North America. The Bally Mountain locality remains largely undescribed, but has already yielded a striking difference in faunal composition when compared to the well-known fissure fills of the Richards Spur locality only 55 kilometers away (Donovan 1987). Decades of descriptions of captorhinids from Richards Spur have yielded new species of single- and multiple-rowed captorhinids (Modesto 1996; May and Cifelli 1998; Kissel et al. 2002), thousands of specimens of Captorhinus aguti (Bolt and Demar 1975; Modesto 1998), but no moradisaurines (MacDougall and Reisz 2012). By comparison, moradisaurines were clearly the most abundant taxon at Bally Mountain (W. May pers. obs.) with Captorhinus aguti being slightly less common. This difference can only be explained by two alternative, but not mutually exclusive hypotheses: (1) the Bally Mountain and Richards Spur fissure fills are not equivalent in age; or (2) the fissure fills at Richards Spur were deposited in a different environment compared to Bally Mountain.

Based on the initial faunal descriptions of Bally Mountain, it is generally accepted that the Bally Mountain fissure fills are equivalent in age to those at Richards Spur (Olson
1967; Donovan 1987; Busbey 1990). They were deposited within caves carved out of the same Ordovician limestone of the Arbuckle Group, they overlie the same oil deposits, they exhibit similar modes of fossil preservation, and preliminary reports suggested they contained very similar early Permian faunas (Donovan 1987; Busbey 1990; Sullivan and Reisz 2002). However, at present it is impossible to determine with any confidence if the Bally Mountain locality is temporally equivalent to the Richards Spur locality without absolute dating (Woodhead et al. 2010). Vertebrate biostratigraphy is the only measure that provides any direct comparisons between the two localities, but the resolution is quite coarse (Olson 1952; Simpson 1979; Woodhead et al. 2010). Interestingly, the vertebrate fauna at Bally Mountain bears similarity to both the Richards Spur locality in Oklahoma and the Vale Formation in Texas. Concerning the former locality, Bally Mountain has yielded the remains of the anamniote Doleserpeton, which is known elsewhere only from Richards Spur (Olson 1967; Bolt 1969). However, Bally Mountain preserves a captorhinid fauna that is apparently more similar to the geologically younger Vale Formation (sensu Lucas 2006) of central Texas than it is to Richards Spur, given that the Vale Formation preserves the only other occurrence of Captorhinikos valensis (Olson 1952, 1954; Modesto et al. 2014). It is possible that Bally Mountain is significantly younger than Richards Spur, possibly by tens of millions of years. However, a more thorough faunal analysis and absolute dating of speleothems would have to be undertaken at the Bally Mountain locality in order to provide a clearer understanding of the biostratigraphy and age of the site.

If the two fissure fill localities in Oklahoma are time-equivalent, then the absence of moradisaurines at Richards Spur may best be explained by environmental differences between the two localities. As a high-fiber herbivore, Captorhinikos valensis may have been more restricted in its distribution when compared to the omnivorous Captorhinus aguti. Herbivores are represented by fragmentary remains of diadectids, caseids, and bolosaurids at Richards Spur; however, they appear to have been rare members of the faunal assemblage (Reisz and Sutherland 2001; Reisz et al. 2002; Reisz 2005). Reisz and Sutherland (2001) suggested that the rarity of diadectid material at this site indicated that Richards Spur was an arid, upland locality with little vegetation to support large populations of herbivorous tetrapods. This would help explain the abundance of Captorhinus aguti at Richards Spur, which would have been more of a generalist, and the lack of any herbivorous moradisaurines. The vegetation at Bally Mountain may therefore have been less sparse and sufficient to support small-bodied herbivores like Captorhinikos valensis in great abundance. 


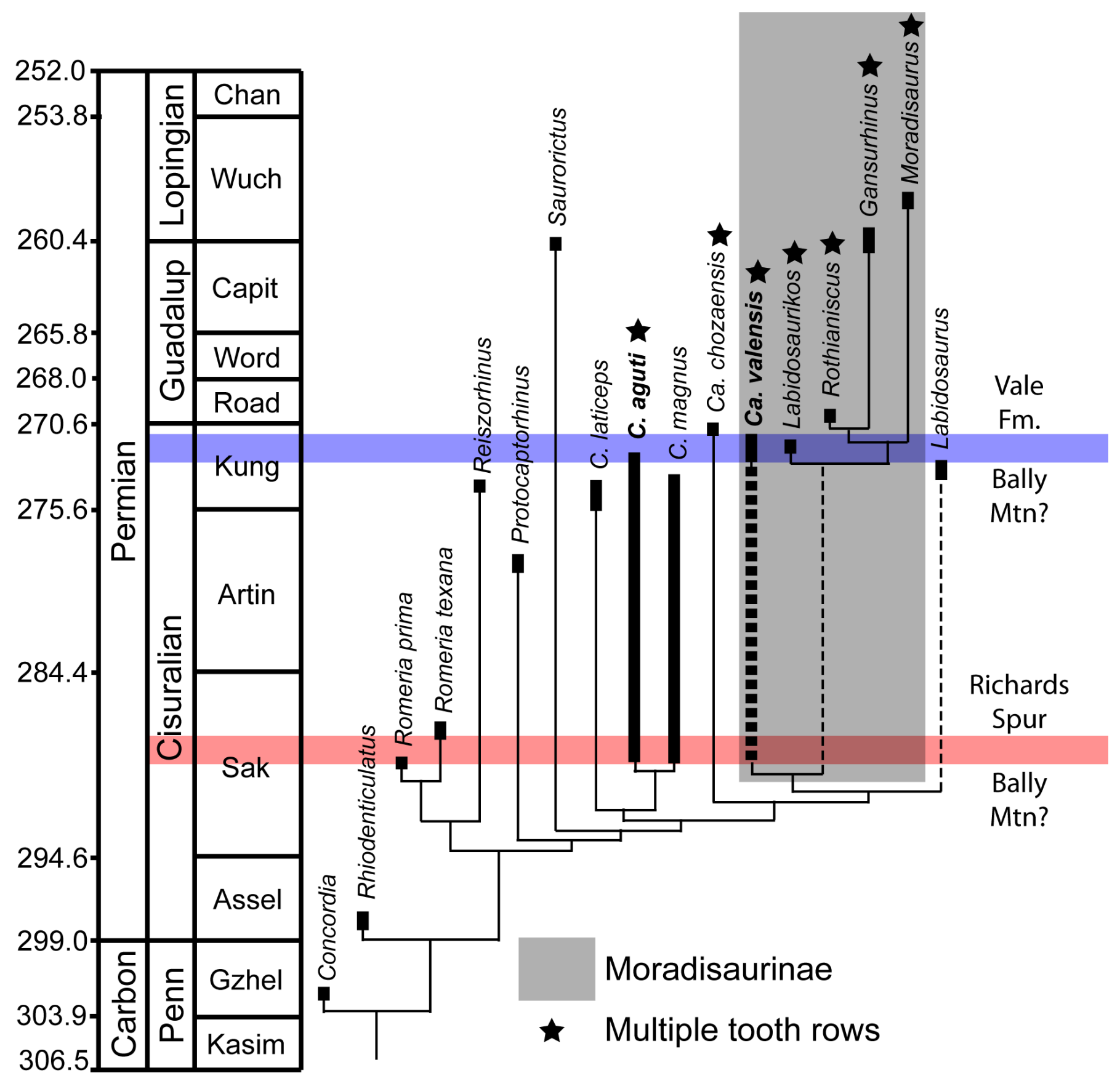

Figure 8. Time-calibrated phylogeny of Captorhinidae showing potential changes to temporal range of Captorhinikos valensis and related ghost lineages based on Bally Mountain material. Blue bar represents the potential chronostratigraphic position of Bally Mountain if it is time-equivalent to the Vale Formation of Texas. Red bar represents the position of Bally Mountain if it is time-equivalent to the Richards Spur locality in Oklahoma.

In addition to possible environmental differences between Bally Mountain and Richards Spur, the presence of moradisaurines at a locality that is of equivalent age to the fissure fills of Richards Spur has major implications for the evolution of high-fiber herbivory in Captorhinidae (Fig. 8) and amniotes in general. If moradisaurine origins can be dated to approximately 289 MYA, then this coincides with the earliest occurrence of the other multiple-rowed captorhinid, Captorhinus aguti. Their co-occurrence suggests that the early evolution of moradisaurines may have been influenced by niche partitioning, given that both taxa were roughly equivalent in body size, co-occurred in time and space, and had multiple rows of teeth. The two groups probably evolved multiple rows of teeth independently (Reisz et al. 2011; Modesto et al. 2014) suggesting that competition would have been pivotal in the establishment of moradisaurines as high-fiber herbivores and C. aguti as an omnivore. Pinpointing the precise age of the Bally Mountain locality is thus incredibly important for testing this hypothesis and determining if interspecific competition 
between captorhinids could have promoted the evolution of high-fiber herbivory, which was clearly a key innovation that promoted the subsequent dispersal and diversification of captorhinids throughout the Permian (Reisz 2006; Modesto et al. 2014). In addition, the presence of a small herbivorous reptile this early in the evolution of the terrestrial vertebrate community would indicate that niche partitioning among herbivores was well underway by the mid-Sakmarian, with Captorhinikos valensis, Edaphosaurus, and Diadectes using extensive oral processing and tooth on tooth grinding of plant materials at different body sizes, with $C a$. valensis clearly being the smallest known herbivore of its time (Reisz and Fröbisch 2014).

\section{CONCLUSIONS}

The fauna of the early Permian fissure fills of the Bally Mountain locality in southwestern Oklahoma remains largely undescribed, but has already yielded a wealth of information on the early evolutionary history of captorhinids, one of the first amniote clades to diversify as high-fiber herbivores (Reisz 2006; Modesto et al. 2014). These first formal descriptions of the multiple-rowed captorhinids from the early Permian fissure fills of the Bally Mountain locality in Oklahoma, U. S. A., provide compelling evidence that Captorhinus aguti, a well known form from other early Permian localities in Oklahoma and Texas, and the earliest moradisaurines co-existed across a wider geographic distribution than previously thought. Furthermore, the description of new material of the early moradisaurine Captorhinkos valensis from Bally Mountain may also extend the temporal range of the earliest herbivorous captorhinids, making it time-equivalent to the earliest occurrence of Captorhinus aguti. The co-occurrence of $C$. aguti and Ca. valensis, both small-bodied, multiple-rowed captorhinids, provides a window into the possible drivers of the origin and diversification of the herbivorous moradisaurines, but more data must first be collected from the locality to glean better resolution of the timing of this diversification. The Bally Mountain locality may thus play an important role in our future understanding of the structure of early Permian terrestrial communities, the evolution of herbivory (Reisz and Fröbisch 2014), and the diversification of early amniotes.

\section{ACKNOWLEDGEMENTS}

We would like to thank D. Leatherbury for granting access to the Bally Mountain quarry. Thanks to J. Larsen of the OMNH for assistance in cataloguing the material. We are grateful to D. Scott for her skilful preparation and photography of the captorhinid specimens figured in this paper. We also thank N. Wong Ken for illustrating several specimens from Bally Mountain. We wish to thank M. MacDougall, D. Scott, and S. Modesto for helpful discussions. Lastly, we thank two anonymous reviewers for their helpful and constructive comments.

\section{LITERATURE CITED}

Benton, M.J. 1984. Tooth form, growth, and function in Triassic rhynchosaurs (Reptilia, Diapsida). Palaeontology 27:737-776.

Bolt, J.R. 1969. Lissamphibian origins: possible protolissamphibian from the lower Permian of Oklahoma. Science 166:888-891.

Bolt, J.R., and R.E. Demar. 1975. An explanatory model of the evolution of multiple rows of teeth in Captorhinus aguti. Journal of Paleontology 49:814-832.

Brink, K.S., R.R. Reisz, A.R.H. LeBlanc, R.S. Chang, Y.C. Lee, C.C. Chiang, T. Huang, and D.C. Evans. 2015. Developmental and evolutionary novelty in the serrated teeth of theropod dinosaurs. Scientific Reports 5:12338.

Busbey, A.B. 1990. The Bally Mountain lower Permian vertebrate locality, Kiowa Co., Oklahoma. Journal of Vertebrate Paleontology 10 (Supplement to number 3):16A.

Dodick, J.T., and S.P. Modesto. 1995. The cranial anatomy of the captorhinid reptile Labidosaurikos meachami from the lower Permian of Oklahoma. Palaeontology 38:687-711.

Donovan, R.N. 1987. The world's smallest oil field? Oklahoma Geology Notes 47:238 \& 291.

Fox, R.C., and M.C. Bowman. 1966. Osteology and relationships of Captorhinus aguti (Cope) (Reptilia: Captorhinomorpha). The University of Kansas Paleontological Contributions, Vertebrata 11:1-79.

Heaton, M.J. 1979. Cranial anatomy of primitive captorhinid reptiles from the Late Pennsylvanian and early Permian Oklahoma and Texas. Oklahoma Geological Survey Bulletin 127:1-84.

Hentz, T.F. 1988. Lithostratigraphy and paleoenvironments of Upper Paleozoic continental red beds, north-central Texas: Bowie (new) and Wichita (revised) groups. Texas Bureau of Economic Geology Report of Investigations 170:1-55.

Kissel, R.A., D.W. Dilkes, and R.R. Reisz. 2002. Captorbinus magnus, a new captorhinid (Amniota: Eureptilia) from the lower Permian of Oklahoma, with new evidence on the homology of the astragalus. Canadian Journal of Earth Sciences 39:1363-1372.

LeBlanc, A.R.H., and R.R. Reisz. 2015. Patterns of tooth development and replacement in captorhinid reptiles: a comparative approach for understanding the origin of multiple tooth rows. Journal of Vertebrate Paleontology e919928.

Laurenti, J.N. 1768. Classis Reptilium. Specimen medicum, exhibens synopsis Reptilium emendatum, cum experimentis circa venena et antidote Reptilium Austriacorum. J. Thom., Nob, et Trattnern, Vienna.

Lucas, S.G. 2006. Global Permian tetrapod biostratigraphy and biochronology. Geological Society of London, Special Publications 265:65-93. 
MacDougall, M.J., and R.R. Reisz. 2012. A new parareptile (Parareptilia, Lanthanosuchoidea) from the early Permian of Oklahoma. Journal of Vertebrate Paleontology 32:1018-1026.

May, W.J., and R.L. Cifelli. 1998. Baeotherates fortsillensis, a new captorhinid reptile from the Fort Sill fissures. Oklahoma Geology Notes 58:128-137.

Modesto, S.P. 1996. A basal captorhinid reptile from the Fort Sill fissures, lower Permian of Oklahoma. Oklahoma Geology Notes 56:4-14.

Modesto, S.P. 1998. New information on the skull of the early Permian reptile Captorhinus aguti. PaleoBios 18:21-35.

Modesto, S.P., A.J. Lamb, and R.R. Reisz. 2014. The captorhinid reptile Captorhinikos valensis from the lower Permian Vale Formation of Texas, and the evolution of herbivory in eureptiles. Journal of Vertebrate Paleontology 34:291-302.

Modesto, S.P., D.M. Scott, D.S. Berman, J. Müller, and R.R. Reisz. 2007. The skull and the palaeoecological significance of Labidosaurus hamatus, a captorhinid reptile from the lower Permian of Texas. Zoological Journal of the Linnean Society 149:237-262.

Müller, J., and R.R. Reisz. 2005. An early captorhinid reptile (Amniota, Eureptilia) from the Upper Carboniferous of Hamilton, Kansas. Journal of Vertebrate Paleontology 25:561-568.

O'Keefe, F.R., C.A. Sidor, H.C.E. Larsson, A. Maga, and O. Ide. 2005. The vertebrate fauna of the upper Permian of Niger-III, morphology and ontogeny of the hindlimb of Moradisaurus grandis (Reptilia, Captorhinidae). Journal of Vertebrate Paleontology 25:309-319.

Olson, E.C. 1952. The evolution of a Permian vertebrate chronofauna. Evolution 6:181.

Olson, E.C. 1954. Fauna of the Vale and Choza: 9. Captorhinomorpha. Fieldiana: Geology 10:211-218.

Olson, E.C. 1967. Early Permian vertebrates of Oklahoma. Oklahoma Geological Survey 74:1-111.

Reisz, R.R. 1997. The origin and early evolutionary history of amniotes. Trends in Ecology and Evolution 12:218-222.

Reisz, R.R. 2005. Oromycter, a new caseid from the lower Permian of Oklahoma. Journal of Vertebrate Paleontology 25:905-910.

Reisz, R.R. 2006. Origin of dental occlusion in tetrapods: signal for terrestrial vertebrate evolution? Journal of Experimental Zoology Part B: Molecular and Developmental Evolution 306B:261-277.
Reisz, R.R., and T.E. Sutherland. 2001. A diadectid (Tetrapoda: Diadectomorpha) from the lower Permian fissure fills of the Dolese Quarry, near Richards Spur, Oklahoma. Annals of the Carnegie Museum 70:133-142.

Reisz, R.R., and J. Fröbisch. 2014. The oldest caseid synapsid from the Late Pennsylvanian of Kansas, and the evolution of herbivory in terrestrial vertebrates. PLoS ONE 9:e94518.

Reisz, R.R., V. Barkas, and D. Scott. 2002. A new early Permian bolosaurid reptile from the Richards Spur Dolese Brothers Quarry, near Fort Sill, Oklahoma. Journal of Vertebrate Paleontology 22:23-28.

Reisz, R.R., J. Liu, J.-L. Li, and J. Müller. 2011. A new captorhinid reptile, Gansurhinus qingtoushanensis, gen. et sp. nov., from the Permian of China. Naturwissenschaften 98:435-441.

Reisz, R.R., A.R.H. LeBlanc, C.A. Sidor, D. Scott, and W. May. 2015. A new captorhinid reptile from the lower Permian of Oklahoma showing remarkable dental and mandibular convergence with microsaurian tetrapods. The Science of Nature 102.

de Ricqlès, A., and P. Taquet. 1982. La faune de vertebres de Permien supérieur du Niger. I. Le captorhinomorphe Moradisaurus grandis (Reptilia, Cotylosauria)-le crane. Annales de Paléontologie 68:33-63.

de Ricqlès, A., and J. R. Bolt. 1983. Jaw growth and tooth replacement in Captorbinus aguti (Reptilia: Captorhinomorpha): a morphological and histological analysis. Journal of Vertebrate Paleontology 3:7-24.

Simpson, L. C. 1979. Upper Gearyan and Lower Leonardian terrestrial vertebrate faunas of Oklahoma. Oklahoma Geology Notes 39:3-19.

Sullivan, C., and R.R. Reisz. 2002. Lower Permian fissure deposits in the Slick Hills, Oklahoma, the oldest known fossiliferous palaeokarst. Journal of Vertebrate Paleontology 22 (Supplement to 3):112A.

Swofford, D.L. 2002. Phylogenetic Analysis Using Parsimony (*And Other Methods). Sinaeur Associates, Sunderland, Massachusetts.

Woodhead, J., R.R. Reisz, D. Fox, R. Drysdale, J. Hellstrom, R. Maas, H. Cheng, and R.L. Edwards. 2010. Speleothem climate records from deep time? Exploring the potential with an example from the Permian. Geology 38:455-458. 
APPENDIX 1. Data matrix used for the phylogenetic analysis (modified from Reisz et al. 2015).

Protorothyris

000000000000000000010001001000001000000000000100000000000000000000111 ? 011??

Paleothyris

$00000000000000001001000000020000000000000000000 ? 000000000000$ 0???00111101111

Thuringothyris

0000010100001001100001000011000010000000000101000000000 ??000 ????0011?? 01011

Concordia

0100110000001101100010 10?001100 0001000?00 0001000?00 0000?00000 0???0????? ?????

Romeria prima

1111010000001000000111010000 ?0 0001001?0? ?0?1010000 10?0?10000 0???0?0?0? 1?0??

Romeria texana

1111010000 00??001001 11010011?0 000100100? 00010?0?0? 10?0010000 0???0????? ?????

Protocaptorhinus

11110100000011000000110 ?000101 001101???1 ?0010?0??0 1000??0000 0???110??1 020??

Rhiodenticulatus

1101010000001101100010100011 ?? ?01101?101 000101000? 1?00010000 01???1?01? 020??

Saurorictus

?111110000 001?000000 001000000 ? ??110????? ???1?????? ?0???100?? ?????????? ?????

Captorhinus laticeps

111111000100110000011010011101001102110200111110001000011001010021000002000

Captorhinus aguti

111111101201110000001010011101001102110200111110001000011001010021000002000

Captorhinus magnus

1111110002001100000010100111010011021102001 ?111000 1000011001 010?2100?? 120??

Labidosaurus

111111010100101011101010011111011102110100112110011111011111111111000012001

Labidosaurikos

11111221331210101110101011011111111211111111211101111102 ?111 10111 ??????????

Moradisaurus

1 ?11022033 011?01??1? ?????2?11? 1???111111 1112211111 ?110121111 1011120??? 1?00?

Rothianiscus

1 111031123 12??1????0 ????12?11? 1????1111? 1212?11??? ?????2?111 ????1200?? 0?0??

Captorhinikos valensis

???1?12023 02,??????? ????????1? ?????????? 000 ??????? ?????211??? ?????20??? ?????

Gansurhinus

1 ??1,32 12300 ???????? ?????????? ?????????? ??????11??? ????1,???? ?????2200?? ?2???

Captorhinikos chozensis

111111111011 ?:0000?1 ?????1?10?????????01 001??1???? 1??1?20101 1???11?000 110?0

Reiszorhinus

111101000000100100001000001100000101 ???? ?????????? 1000?10010 ?11?0????? ????? 